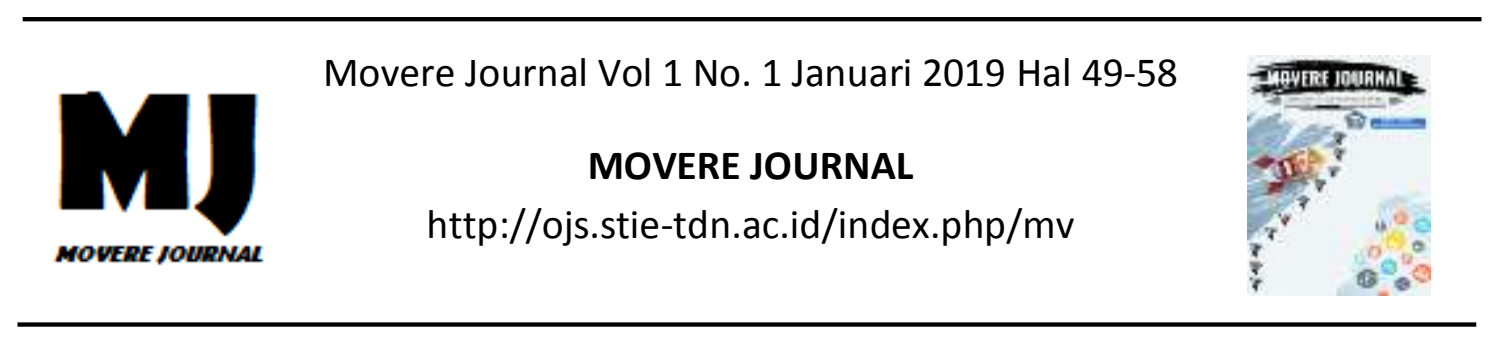

\title{
MODIFIKASI TEORI PERSONALITI PENINGKATAN KOMPETENSI KEWIRAUSAHAAN DAN KINERJA USAHA PENJUAL GARMEN PADA USAHA KECIL MENENGAH (UKM) DI KOTA MAKASSAR
}

\author{
Muhammad Yunus \\ Fakultas Ekonomi dan Bisnis \\ Universitas Muhammadiyah Parepare
}

\begin{abstract}
Abstrak : Penelitian ini bertujuan untuk mengetahui faktor-faktor yang mempengaruhi (i) karakteristik individu terhadap kompetensi kewirausahaan, (ii) sumberdaya manusia terhadap kompetensi kewirausahaan, (iii) orientasi kewirausahaan terhadap kompetensi kewirausahaaan (iv) lingkungan terhadap kompetensi kewirausahaan dan (v) kompetensi kewirausahaan terhadap kinerja usaha. Penelitian ini termasuk dalam kategori penelitian eksplanasi (explanatory research). Penelitian dilakukan pada usaha kecil menengah yang tersebar di Kota Makassar. Populasi penelitian adalah usaha kecil menengah pada sektor ekonomi pengusaha tekstil dan pengusaha pakaian jadi yang berdasarkan pada data tahun tahun 2013-2014. Jumlah UKM megalami penurunanan 1,85 \% dan 5,36 \% masing-masing tahun 2013 dan 2014. Teknik pengambilan sampel menggunakan teknik sampel (Stratified random sampling), (stratified random sampling), yakni mengambil sampel secara acak berstrata (kelompok) dengan jumlah sampel sebanyak 300 pengusaha. Pada penelitian ini, faktor-faktor kontekstual, sebagai variabel independen, diuji sebagai prediktor potensial dari dimensi masing-masing prediktor untuk komponen kinerja kewirausahaan. Hasil penelitian ini menunjukkan bahwa variabel karakteristik individu, sumberdaya manusia, orientasi kewirausahaan, dan lingkungan bersama dengan masing-masing dimensinya menunjukkan bahwa ada pengaruh signifikan antara variabel eksogeng dengan variabel endogen secara simultan dan parsial terhadap kompetensi kewirausahaan maupun terhadap kinerja usaha.
\end{abstract}

Kata kunci : keperibadian, lingkungan, kompetensi kewirausahaan dan kinerja usaha

\section{PENDAHULUAN}

Upaya pengembangan usaha kecil menengah (UKM) akan berhadapan dengan kendala-kendala tertentu yaitu ketika mereka 'diminta' menjalankan fungsi produksi, maka kompetensi sesorang harus dimiliki. Sebuah budaya yang memiliki sikap kewirausahaan menciptakan lingkungan pembelajaran yang bersumber dari eksplorasi dan eksperimen yang diwujudkan dalam bentuk kreatifitas dan inovasi. Sedangkan indikasi nyata dari berhasilnya pembelajaran adalah kompetensi pengetahuan yang dimiliki untuk selanjutnya akan tercermin dalam sebuah kinerja optimal bagi personelpersonel yang berhubungan langsung dengan pasar dan terikat dalam pola organisasi yang formalmaupun informal. Saat ini, orientasi kewirausahaan telah menjadi sesuatu yang kritis dan mendesak bagi perusahaan yang menghadapi persaingan dan tekanan dalam pasar yang terus meningkat. Ini relevan dengan kondisi lingkungan 
bisnis yang juga semakin dinamis, oleh karenanya, manajer dalam setiap level harus terus mencari dan terus belajar menanggulangi ketidakpastian agar fungsi strategisnya dapat lebih kompetitif.

Berdasarkan data Badan Pusat Statistik (www.bps.go.id) diketahui bahwa angkatan kerja yang menganggur mempunyai latar belakang pendidikan yang berbeda. Tercatat jumlah pengangguran terbuka lulusan perguruan tinggi mengalami peningkatan dari tahun 2009 (Agustus) menuju 2010 (Februari) sebesar 1,16 persen. Meningkatnya jumlah pengangguran terbuka tingkat perguruan tinggi Idisebabkan oleh adanya ketidak sesuaian antara bidang keahlian lulusan dengan tuntutan kualifikasi yang dibutuhkan oleh perusahaan pencari tenaga kerja ataukah kurangnya pengetahuan yang dimiliki oleh lulusan perguruan tinggi untuk menjadi seorang pengusaha.

Perkembangan UMKM tahun 2010 naik sebesar $0,12 \%$ yakni 51.409612 unit naik menjadi 52764 603 unit pada tahun 2011. tahun 2011 turun sebesar $0,63 \%$ yakni 52.764 .603 unit naik menjadi 53.823.732 unit pada tahun 2012. Pada tahun 2012 ke 2013 UMKM naik sebesar 0,56 \% yakni 53.823.732 unit pada tahun 2012 menjdai 55.206.444 unit pada tahun 2013. Kemudian pada tahun 2013 ke 2014 JumlahUMKM berkurang sebesar $0,16 \%$ yakni 55 206444 unit tahun 2013 menjadi 56.534.592 unit tahun 2014. Sementara yang lain seperti pertumbuhan jumlah tenaga kerja pada tahun 2014 naik sebesar 5,83\% dari tahun 2013 yakni 2,33\% pada tahun 2014. Kemudian sumbangan PDB UMKM (harga konstan) 9,9\% yakni dari tahun 2013 yakni $\mathrm{Rp}$ 1.369.326,00 menjadi 1.504.928,20 pada tahun 2014 (dalam Milyar Rp). Demikian juga pertumbuhan nilai export juga mengalami pertumbuhan sebesat $11 \%$ tahun 2013 ke tahun 2014 (6,56 \% menjadi 11,00\%). Pertumbuhan jumlah UMKM yang mana dalam hal ini UKM merupakan bahagian dari UMKM dalam hal ini menurunnya jumlah pertumbuhan jumlah UMKM. Berarti UKM juga menjadi masalah karena hal ini kemungkinan penyebab menurunnya minat, niat untuk berusaha kencendrungannya lebih menurun.

Menurut Zulfadhli dalam Tribun News.com Menya takan bahwa :"Tingkat kemajuan dan kesejahteraan sebuah negara dilihat dari berapa jumlah wirausaha dalam suatu negara, sedikitnya yang harus dimiliki sebanyak 2 persen dari total penduduk, dengan jumlah penduduk Indonesia sebanyak 237 juta jiwa, maka Indonesia membutuhkan sekitar 4,5 juta lebih wirausahawan. Hanya saja Indonesia saat ini baru memiliki sekitar 0,24 persen atau sekitar 590 ribu wirausahawan. Jumlah ini jauh dari target minimal sebesar 2 persen atau 4,5 juta wirausahawan". (http://id.berita.yahoo.com).

Di Sulawesi Selatan pertumbuhan jumlah UMKM dari tahun 2010 sampai 2014 umumnya mengalami penurunan sementara pertumbuhan jumlah tenaga kerja mengalami peningkatan. Penyebab terjadinya perubahan pada sektor UKM karena berubahnya 1) karakteristik individu seperti perilaku, umur tingkat, pendidikan, kompetensi 2) sumberdaya manusia, seperti keahlian, pemgalaman, resiko, komitmen. 3) Orientasi kewira usahaan seperti sikap, motivasi dan niat. dan 4) Faktor lingkungan seperti ketersediaan fasilitas kredit. Jika ini semua menjadi lemah berarti produktifitas usaha mengalami penurunan. 


\section{TINJAUAN PUSTAKA}

\section{Usaha Kecil dan Menengah (UKM)}

Berdasarkan UU No. 9 tahun 1995, usaha kecil dan menengah memiliki kriteria sebagai berikut: a. Kekayaan bersih paling banyak Rp 200 juta tidak termasuk tanah dan bangunan tempat usaha. b. Memiliki hasil penjualan tahunan paling banyak Rp 1 miliar. c. Milik Warga Negara Indonesia (WNI) d. Berdiri sendiri, bukan merupakan anak perusahaan atau cabang perusahaan yang dimiliki atau dikuasai usaha besar. e. Bentuk usaha orang perorang, badan usaha berbadan hukum/tidak, termasuk koperasi. f. Untuk sektor industri, memiliki total aset maksimal $\mathrm{Rp} 5$ miliar. g. Untuk sektor non industri, memiliki kekayaan bersih paling banyak Rp 600 juta (tidak termasuk tana dan bangunan tempat usaha), atau memiliki hasil penjualan tahunan maksimal $\mathrm{Rp} 3$ miliar pada usaha yang dibiayai.

Standard yang digunakan dinas Perindagkop mengklasifikasikan UKM sesuai UU No 9 Tahun 1995 yang berdasarkan investasi perusahaan. Investasi tersebut sebagai berikut:

\section{Tabel 2.1 : Kriteria Usaha Rumah Tangga, Kecil, Menengah, dan Besar}

\begin{tabular}{llc}
\hline No & Kelompok Usaha & Kritera \\
\hline 1 & Usaha rumah tangga & $<5$ Juta \\
2 & Usaha Kecil & $5-200 \mathrm{Juta}$ \\
3 & Usaha menengah & $201-1$ milyar \\
4 & Usaha besar & $>1$ Milyar \\
\hline Sumber : Depkumham 2008
\end{tabular}

\section{Kinerja Usaha}

Kinerja dapat dilihat dari tingkat penjualan, profitabilitas, tingkat pengembalian modal, tingkat omset dan pangsa pasar yang diperoleh (Jauch dan Glueck, 1998). Li, H., Zhang, Y. and Chan, T.S. (2005) menggunakan 3 indikator kinerja pengukuran efisiensi, pertumbuhan, dan keuntungan (Sanchez dan Marin, 2005). Kinerja merupakan perilaku nyata yang ditampilkan setiap orang sebagai prestasi kerja yang dihasilkan oleh karyawan sesuai dengan perannya dalam perusa-haan (Jangwoo, Lee, Danny Miller. 1996.). Tercapainya kinerja usaha yang untuk membuat usaha berkesinambungan sangat tergantung pada Karakteristik Individu, sumberdaya manusiaa, orientasi, lingkungang, kompetensi (Yusuff. Olabisi, Sherifat, Andrew Akinola Olagbemi. Adewole Akinwole Atere $\mathrm{PhD}, 2011)$.

\section{Karakteristik individu}

Karakteristik merupakan suatu kekuatan dan kelemahan dibandingkan dengan yang dimiliki individu. Dengan demikian, pengumpulan data profil, pengalaman, keterampilan manajemen dan kompetensi, karakteristik individu dan motif pengusaha mempengaruhi kinerja usaha. Para pembuat kebijakan harus melanjutkan upaya mereka dalam memelihara lebih banyak pengusaha dan juga untuk memfasilitasi keberhasilan mereka. (Li, H., Zhang, Y. and Chan, T.S.(2005).

\section{Sumberdaya Manusia}

(Christine G. Ishengoma, 2011). Menurutnya sumberdaya manusia, pembelajaran seperti pelatihan merupakan alat dalam proses menangani keseimbangan pengusaha. Sebagian besar temuan dari studi menunjukkan bahwa : 
a) Kurangnya satu aksesibilitas pada kekuatan pengambilan keputusan.

b) Kurangnya akses terhadap permodalan.

c) Faktor lain, seperti kurangnya minat dan motivasi untuk menjadi pengusaha.

Sumberdaya manusia memiliki akses dalam berwirausaha (Becker, 1995). Hambatan utama untuk kinerja yang efisien dari beberapa kegiatan. Hal ini karena pengambilan keputusan dan kontrol atas sumber daya (Makundi, 1996). Kemudian dari segi konteks pemikiran, masih perlu pengembangan lebih mendalam (C. Callhaghan \& R. Venter, 2011).

\section{Orientasi kewirausahaan}

Orientasi kewirausahaan yang meliputi kepercayaan diri, keberanian, kemauan yang kuat, risiko, kreativitas, inovasi, dan sebagainya harus dimiliki, jika ingin menjadi pengusaha. Ini bisa diperoleh melui pendidikan (Hasni Che Ismail, 2012). hubungan yang signifikan antara orientasi kewirausahaan dan kinerja, sedangkan keunggulan kompetitif ditemukan untuk memediasi orientasi menuju kinerja kewirausahaan, (Rosli Mahmood. Norshafizah Hanafi 2013). Inovasi, proaktif, kecendrungan mengambil resiko, kompetitif, sikap, agresif, otonomi merupakan variabel yang mempengaruhi kinerja usaha (Arslan Ayub, Adeel Razzaq, Muhammad Salman Aslam, Hanan Iftekhar, 2013).

\section{Faktor Lingkungan}

Isidore Ekpe Norsiah Mat \& Razli Che Razak (2011) menurutnya atribut individu seperti pendidikan, pengalaman dan sikap terhadap pengambilan risiko penting untuk aktivitas pengusaha. Faktor lingkungan bisnis, sepert kredit. Isidore Ekpe, Norsiah Mat (2012) menyatalakan bahwa orientasi kewirausahaan seperti niat. Demikian juga lingkungan sosial (keluarga dan sahabat/teman).

\section{Kompetensi kewirausahaan}

UKM harus dilengkapi dengan tiga kompetensi, yaitu (1). Kekuatn (fokus pada peluang bisnis dan nilainilai inovasi) (2).Kemampuan (berfokus pada manajemen dan perencanaan yang efektif, pengorganisasian, koordinasi, dan kontrol), dan (3). Kompetensi teknis (berfokus pada ilmu pengetahuan dan teknologi, dan inovasi untuk orientasi konsumen (Hee Song Ng, Daisy Mui Hung Kee, PhD 2013). Hubungan antara kompetensi wirausaha dan kinerja usaha. Dalam organisasi program pemikiran yang kolektif. yang membedakan anggota satu organisasi dengan yang lain ( Hee Song $\mathrm{Ng}$ dan Daisy Mui Hung Kee, PhD, 2013).

\section{Pengembangan Hipotesis}

Adapun pengembangan hipotesis dalam penelitian ini dirumuskan empat hipotesis yakni diduga bahwa :

1. Ada pengaruh secara simultan dan parsial karakteristik individu, sumberdaya manusia, orientasi kewirausahaan dan faktor lingkungan terhadap kinerja usaha pada usaha kecil menengah (UKM).

2. Ada pengaruh dimensi masingmasing karakteristik individu, sumberdaya manusia, orientasi kewira usahaan dan faktor lingkungan secra simultan dan parsial terhadap kinerja usaha pada usaha kecil menengah (UKM).

\section{METODE PENELITIAN}

Jenis Penelitian dan Lokasi

\section{Penelitian}

Penelitian ini termasuk penelitian dan pengembangan (Research \& Development) yaitu pengembangan usaha yang berbasis pada kompetensi dan kewirausahaan. 
Penelitian ini dilaksanakan di Kota Makassar.

\section{Metode Penentuan Sampel}

Kajian penelitian ini dilaksanakan di, Kota Makassar dengan unit analisis yaitu pengaruh konpetensi kewirausahaan terhadap kinerja usaha kecil dan menegah (UKM). Penentuan sampel dilakukan dengan cara stratified. Populasi dalam penelitian ini adalah pemilik atau pendiri UKM yang tersebar di beberapa tempat di 2 Kota dan 1 Kabupaten Propinsi Sulawesi Selatan yakni Makassar. Jumlah sampel yang akan diambil sebanyak 300.

\section{Metode Pengumpulan Data}

Metode pengumpulan data yang digunakan dalam penelitian ini adalah: Kuesioner (angket), Observasi, Wawancara (interview),

\section{Definisi Operasional}

1. Karakteristuik individu adalah Suatu sifat atau watak atau keperibadian yang khas dari seseorang, setiap individu mempunyai karakteristik bawaan (heredity) dan karakteristik yang dipengaruhi oleh lingkungan. Benny M. E. De Waal and Paul Breman (2012)

2. Sumber daya manusia adalah himpunan individu yang membentuk tenaga kerja organisasi, sektor bisnis, atau ekonomi. Arslan Ayub, Adeel Razzaq, Muhammad Salman Aslam, Hanan Iftekhar (2013).

3. Orientasi kewirausahaan adalah Aktivitas wirausaha dianggap sebagai kegiatan pengembangan ekonomi yang mendukung penciptaan kesejahteraan dan lapangan kerja. C. Callaghan \& R. Venter (2011) menurutnya attitude, motivation, motivasi Intention merupakan faktor yang menetukan pengembangan entrepreneurial orientation.

4. Faktor lingkungan menurut Isidore Ekpe Norsiah Mat \& Razli Che Razak (2011) menutnya 1) Atribut individu (pendidikan, pengalaman dan sikap terhadap pengambilan risiko) dan 2) Faktor lingkungan bisnis seperti, saingan, kredit, sahabat dan keluarga.

5. Kompetensi Kerwirausahaan yaitu kemampuan melaksanakan semua tugas yang ada dalam pekerjaannya sesuai dengan standar yang diharapkan. (Isidore Ekpe Norsiah Mat \& Razli Che Razak (2011) menurutnya faktor kompetensi berwirausaha seperti skill, ability, Creativity and Action.

6. Kinerja usaha adalah semua penomena pada lingkungan kerja khususnya pada sektor yang berhubungan dengan aktifitas manusia untuk menentukan berhasil tidaknya suatu kegiatan usaha seperti keuntungan dan kepuasan berkelanjutan (Ojokuku, R.M. 2013).

\section{Sumber dan Cara Menentukan Data}

Sumber data adalah pengusaha tekstil dan pengusaha pakaian jadi yang ada di Makassar. Cara menentukan sampel dengan rumus Slovin

$$
\mathrm{n}=\mathrm{N} / 1+\mathrm{N}(\mathrm{e})^{2}
$$

Untuk mengetahui valid tidaknya data yang digunakan dalam variabel penelitian maka digunakan uji validitas. Setiap indikator yang digunakan menunjukkan nilai significan corelation $<\alpha(5 \%)$ sebagai hasil uji agar semua variabel yang digunakan pada indicator /instrument penelitian valid.

\section{Teknik Pengumpulan Data}

Data yang digunakan dalam penelitian ini adalah pertama data 
primer yang diperoleh melalui observasi yang dilakukan dengan cara pengamatan langsung pada aktivitas objek penelitian (responden). Data direncanakan dengan penyebaran kuesioner secara langsung kepada obyek penelitian (responden) dengan memberi beberapa pertanyaan atau pernyataan tertulis pada responden. Terakhir wawancara (interview) yang mrupakan bentuk pengumpulan data secara langsung.

\section{Rancangan Analisis data dan Uji Hipotesis}

Dalam penelitian ini metode analisis yang digunakan untuk pengujian hipotesis dalam penelitian ini dengan menggunakan teknik analisis data SEM (Structural Equation Modelling) untuk .melihat hubungan dan keterkaitan di antara baik secara simultan maupun secara parsial.

\section{Uji Instrumen}

\section{PEMBAHASAN}

Hasil penelitian dengan Output Anova menunjukkan nilai $\mathrm{F}$ hitung adalah sebesar 3.677 dengan signifikan 0.013 dengan demikian dapat disimpulkan bahwa terdapat perbedaan yang signifikan antara instrument variabel independen terhadap dependen, atau dengan kata lain tingkat kepercayaan terhadap intrumen penelitian cukup valid. Kemudian uji koefisien nilai $\mathrm{t}$ hitung sebesar 6,523 dengan sig 0.00. t hitun $6,523>\mathrm{t}$ tabel 1,649 sementara tingkat sig, $0,00<0,05$. Ini berarti instrumen penelitian cukup valid mendukung penelitian.

Analisis Estimasi dan Uji Kecocokan Karakteristik Individu, Sumberdaya Manusia, Orientasi kewirausahaan, lingkungan, Kompetensi kewirausahaan dan Kinerja usaha. Masing-masing dengan dimensinya dengan dimensinya bahwa Variabel Karaktersitik Individu, nilai regression wieight dimana CR 8,87. 8,92. 5,98 lebih besar dari angka 1,96 (standar signifkan $>1,96$ ). Juga menegenai probabilita nilainya lebih kecil dari $0,05 \quad(<0,05)$. Ini dapat dinyatakan bahwa semua indikator sumberdaya manusia dinyatakan valid. Untuk variabel Sumberdaya Manusia nilai CR 2,77. 2,81 dan 2,55 lebih besar dari angka 1,96 (standar signifkan > 1,96). Juga menegenai probabilita nilainya lebih kecil dari 0,05 (< 0,05). Ini dapat dinyatakan bahwa semua indikator sumberdaya manusia dinyatakan valid. Untuk variabel orientasi kewirausahaan nilai CR 6,51. 30,70. 44,53 lebih besar dari angka 1,96 (standar signifkan > 1,96). Juga menegenai probabilita nilainya lebih kecil dari 0,05 $(<0,05)$. Ini dapat dinyatakan bahwa semua indikator orientasi kewirausahaan dinyatakan valid.Untuk variabel Lingkungan nilai CR 19,31. 5,40. 5,61 lebih besar dari angka 1,96 (standar signifkan > 1,96). Juga menegenai probabilita nilainya lebih kecil dari 0,05 $(<0,05)$. Ini dapat dinyatakan bahwa semua dimensi indikator lingkunag dinyatakan valid. Untuk variabel kompetensi kewirausahaan nilai CR 6,15. 8,39. 8,30 lebih besar dari angka 1,96 (standar signifkan > 1,96). Juga mengenai probabilita nilainya lebih kecil dari 0,05 $(\mathrm{P}<0,05)$. Ini dapat dinyatakan bahwa semua dimensi indikator lingkunag dinyatakan valid. Untuk variabel kinerja usaha nilai $\mathrm{CR}$ 15,33 . 5,63 . 3,09 lebih besar dari angka 1,96 (standar signifkan > 1,96). Juga menegenai probabilita nilainya lebih kecil dari $0,05 \quad(<0,05)$. Ini dapat dinyatakan bahwa semua dimensi indikator lingkunagan dinyatakan valid.

\section{Pengujian hipotesis}

a. Ada pengaruh secara simultan dan parsial karakteristik individu, sumberdaya manusia, orientasi 
kewirausahaan dan faktor lingkungan terhadap kinerja usaha pada usaha kecil menengah (UKM).

Hubungan secara simultan variabel karakteristik individu, sumberdaya manusia, orientasi kewirausahaan dan lingkungan, nilai Probabilita masing-masing variabel lebih kecil dari 0,05 pada $\mathrm{N}=300(0,18.011 .0,002$. ***. *** $<$ 0,05. Artinya secara simultan ada hungan yang signifikan. Selanjutnya secara parsial kita uji variabel satu persatu dimana masing-masing variabel memiliki hubungan signifikansi lebih kecil dari $0,05(\mathrm{P}<0,05)$. Ini berarti bahwa pengaruh secara parsial signifikan.

Hasil penelitian ini menunjukkan bahwa ada pengaruh secara simultan maupun secara parsial variabel independen terhadap variabel dependen. Ini berdasarkan hipotesis variabel independen dan variabel dependen signifikan berarti hipotesis diterima.

Tabel 4.1 : Nilai probabiliti Variabel

\begin{tabular}{|c|c|c|c|c|c|c|c|c|c|}
\hline \multirow{2}{*}{$\begin{array}{l}\text { VARIABEL } \\
\text { DEPENDEN }\end{array}$} & \multirow{2}{*}{$\begin{array}{l}\text { HUBU } \\
\text { NGAN }\end{array}$} & \multicolumn{4}{|c|}{ VARIABEL INDEVENDEN } & \multicolumn{4}{|c|}{ NILAI PROBABILITY } \\
\hline & & 1 & 2 & 3 & 4 & $\begin{array}{c}\text { VAR } \\
1 \\
\end{array}$ & $\begin{array}{c}\text { VAR } \\
2 \\
\end{array}$ & $\begin{array}{c}\text { VAR } \\
3 \\
\end{array}$ & $\begin{array}{c}\text { VAR } \\
4 \\
\end{array}$ \\
\hline $\begin{array}{c}\text { Kompetensi } \\
\text { Kewirausahaan }\end{array}$ & $<---$ & $\begin{array}{c}\text { Karakteristi } \\
\text { k Individu }\end{array}$ & $\begin{array}{c}\text { Sumberd } \\
\text { ayaManu } \\
\text { sia }\end{array}$ & $\begin{array}{c}\text { Orientasi } \\
\text { Kewirausa } \\
\text { haan }\end{array}$ & $\begin{array}{l}\text { Lingkung } \\
\text { an }\end{array}$ & 0,006 & $* * *$ & $\begin{array}{l}0,00 \\
2\end{array}$ & $* * *$ \\
\hline Kinerjausaha & $<---$ & $\begin{array}{l}\text { Karakteristi } \\
\text { k Individu }\end{array}$ & $\begin{array}{c}\text { Sumberd } \\
\text { ayaManu } \\
\text { sia }\end{array}$ & $\begin{array}{c}\text { Orientasi } \\
\text { Kewirausa } \\
\text { haan }\end{array}$ & $\begin{array}{l}\text { Lingkung } \\
\text { an }\end{array}$ & $* * *$ & $* * *$ & $* * *$ & $* * *$ \\
\hline Kinerjausaha & $<---$ & Kompetensi & $\begin{array}{l}\text { Kompete } \\
\text { nsi } \\
\text { Kewiraus } \\
\text { ahaan }\end{array}$ & $\begin{array}{c}\text { Kompeten } \\
\text { si } \\
\text { Kewirausa } \\
\text { haan }\end{array}$ & $\begin{array}{c}\text { Kompeten } \\
\text { si } \\
\text { Kewiraus } \\
\text { ahaan }\end{array}$ & $* * *$ & $* * *$ & $* * *$ & $* * *$ \\
\hline
\end{tabular}

Sumber : Hasil pengolahan data dengan analisis path amos 2016

b. Ada pengaruh dimensi masingmasing karakteristik individu, sumberdaya manusia, orientasi kewira usahaan dan faktor lingkungan secra simultan dan parsial terhadap kinerja usaha pada usaha kecil menengah (UKM).

Dari variabel eksogen dapat di uji dengan Uji $F$ untuk mengetahui pengaruh variabel independen secara bersama-sama (simultan) terhadap variabel terikat. Nilai $F$ dalam analisis SPSS adalah 23,101. Selanjutnya dibandingkan dengan nilai $\mathrm{F}$ tabel pada probabilita 0,05 , nilai $\mathrm{F}$ hitung lebih besar dari $\mathrm{F}$ tabel $(23,101>2,25)$ maka disimpulkan bahwa terdapat pengaruh yang signifikan antara varabel-variabel eksogen dengan indikator masing-masing secara simultan terhadap variabel endogen ( kenerja usaha). Unutk menentukan signifikan atau tidak akan diuji dengan Uji t dengan tingkat kepercayaan $95 \%$ atau $\alpha=0,05$. Untuk mencari nilai $\mathrm{t}$ tabel $=(\alpha / 2) ; \mathrm{n}-\mathrm{k}-1=0,05 / 2 ; 300-5$ $-1=0,025 ; 294$ Nilai pada tabel $\mathrm{t}=$ 1,968, sementara $\mathrm{t}$ hitung untuk variabel karakteristik individu 2,967 > $\mathrm{t}$ tabel 1,968 artinya variabel independen bersama dengan deminsi masing-masing berpengaruh secara parsial terhadap variabel dependen.

Hasil penelitian ini menunjukkan bahwa ada pengaruh secara simultan maupun secara parsial variabel independen terhadap variabel dependen. Ini berdasarkan hipotesis variabel independen dan variabel dependen signifikan berarti hipotesis diterima. 
Hasil penelitian ini juga sejalan dengan pemikiran Olabisi, Sherifat Yusuff. Andrew Akinola Olagbemi. Adewole Akinwole Atere, PhD (2011) menegaskan bahwa kinerja usaha dipengaruhi oleh karakteristik individu, motivasi dan tujuan, sumberdaya, orientasi kewirausahaan dan faktor lingkungan. Perbedaan hasil penelitian ini dengan Yusuff. Olabisi, Sherifat, adalah sumberdaya, motivasi dan tujuan. Motivasi dan tujuan, peneliti jadikan dimensi pada orientasi kewirausahaan sementara sumberdaya peneliti jadikan variabel sumberdaya manusia, karena sumberdaya yang lain tergantung pada permodalan dan ini masuk sebagai fasilitas permodalah yang didukung oleh perbankan. Selanjutnya hasil penelitian ini bahwa semua variabel indevenden mempengaruhi kinerja usaha. Dalam hal ini hipoteis diterima.

\section{Kesimpulan}

1. Pengaruh langsung secara parsial masing-masing karakteristik individu, sumberdaya manusia, orientasi kewirausahaan dan lingkungan terhadap kinerja usaha. Perubahan karakteristik individu, sumberdaya manusia, orientasi kewirausahaan dan lingkungan masing-masing memiliki kecenderungan untuk menentukan peningkatan kinerja usaha. Kondisi pengusaha di Kota Makassar menjelaskan bahwa kinerja usaha ditentukan oleh karakteristik individu, sumberdaya manusia, orientasi kewirausahaan dan lingkungan para pengusaha.

2. Pengaruh tidak langsung secara parsial karakteristik individu, sumberdaya manusia, orientasi kewirausahaan dan lingkungan terhadap kinerja usaha dengan pertimbangan kompetensi kewirausahaan menunjukkan adanya pengaruh positif dan signifikan. Hal tersebut dijelaskan bahwa dengan peningkatan kualitas masing-masing karakteristik individu, sumberdaya manusia, orientasi kewirausahaan dan lingkungan menjadi lebih baik akan meningkatkan kinerja usaha jika disertai pertimbangan kompetensi kewirausahaan.

3. Pengaruh langsung secara simultan karakteristik individu, sumberdaya manusia, orientasi kewirausahaan, lingkungan terhadap kinerja usaha. Hasil penelitian menunjukkan bahwa adanya pengaruh positif dan signifikan. Hal tersebut dijelaskan bahwa dengan peningkatan kualitas karakteristik individu, sumberdaya manusia, orientasi kewirausahaan, lingkungan menjadi lebih baik, secara simultan memiliki kecnderungan meningkatkan kinerja usaha

4. Pengaruh tidak langsung secara simultan karakteristik individu, sumberdaya manusia, orientasi kewirausahaan, lingkungan terhadap kinerja usaha dengan mempertimbangkan kompetensi kewirausahaan. Hasil penelitian menunjukkan bahwa adanya pengaruh positif dan signifikan. Hal tersebut dijelaskan bahwa dengan peningkatan kualitas karakteristik individu, sumberdaya manusia, orientasi kewirausahaan, lingkungan menjadi lebih baik secara simultan akan meningkatkan kinerja usaha dengan pertimbangan kompetensi kewirausahaan para pengusaha di Kota Makassar.

\section{Saran}

1. Sebagai pengusaha tekstil dan pengusaha pakakain jadi perlu memahami bahwa karakteristik individu, sumberdaya manusia, orientasi kewirausahaan, lingkungan sebagai faktor kontekstual keperibadian bagi pengelola usaha 
kecil menengah menjadi kekuatan untuk menopang atau meningkatkan kinerja usaha. Kualitas faktor kontekstual keperibadian, ini perlu diperbaiki kualitasnya agar kecenderungan untuk mempengaruhi dan meningkatkan kinerja usaha

2. Sebagai pengusaha tekstil dan pengusaha pakain jadi perlu memahami bahwa, pengaruh tidak langsung faktor kontekstual keperibadian harus didukung oleh kompetensi kewirausahaan sebagai mediator untuk meningkatkan kinerja usaha. Kualitas masingmasing indikator kompetensi kewiraushaan sebaiknya ditingkatkan kekuatannya untuk mempengaruhi dan meningkatkan kinerja usaha.

3. Sebagai pengusaha tekstil dan pengusaha pakaian jadi sangat penting untuk memahami indikator terkuat dari masing-masing variabel agar dapat dipertahankan atau ditingkatkan kwalitasnya yakni (1) indikataior tingkat pendidikan sebagai indikator variabel karakteristik individu tertinggi (2) indikator kemampuan bersaing sebagai indikator variabel sumberdaya manusia terkuat (3) indikator motivasi sebagai indikator variabel orientasi kewirausahaan terkuat (4) indikator keamanan sebagai indikator variabel lingkungan tertinggi, untuk mempengaruhi atau meningkatkan kinerja usaha.

4. Sebagai pengusaha tekstil dan pengusaha pakaian jadi sangat penting untuk memahami indikator terendah dari masing-masing variabel untuk mendapat perhatian khusus yakni (1) indikator resiko sebagai indikator variabel karakteristik individu terendah. (2) indikator resiko sebagai indikator variabel sumberdaya manusia terendah. (3) indikator niat sebagai indikator variabel orientasi kewirausahaan terendah. (4) indikator keluarga sebagai indikator variabel lingkungan terendah. Masing-masing indikator tersebut memiliki kecendrungan yang rendah untuk mempengaruhi kinerja usaha melalui kompetensi kewirausahaan.

\section{DAFTAR PUSTAKA}

Callaghan C \& R. Venter (2011) An investigation of the entrepreneurial orientation, context and entrepreneurial performance of innercity Johannesburg street traders, Southern African Business Review Volume 15 Number 1

Christine G. Ishengoma, (2011) Accesibility of Resources by Gender: The Case of Morogoro Regeion in Tanzania

Ekpe Isidore, Norsiah Mat \& Razli Che Razak (2011), Attributes, Environment Factors and Women Entrepreneurial Activity: A Literature Review. College of Business, Universiti Utara Malaysia, 06010 Sintok, Darul Aman, Malaysia

Hasni Che Ismail, Faridahwati Mohd. Shamsudin, Mohammed S. Chowdhury (2012), An Exploratory Study of Motivational Factors on Women Entrepreneurship Venturing in Malaysia, Universiti Utara Malaysia, 06010 Sintok, Kedah, Malaysia. http://id.berita.yahoo.com).

Zulfadhli dalam Tribun News.com. 2015.Lung Choe Kum, SiatChing Loo \& Teck-Chai Lau (2013) Exploratory Study on 
The Relationship between Entrepreneurial Attitude and Firm's Performance. Faculty of Business and Finance, Universiti Tunku Abdul Rahman, Kampar, Malaysia.

Song Hee $\mathrm{Ng}$ dan Daisy Mui Hung Kee, PhD (2013). Effect of entrepreneurial competencies on firm performance under the influence of organizational culture. School of Management, Universiti Sains Malaysia, 11800 USM Penang Malaysia.

Yusuff. Olabisi, Sherifat, Andrew Akinola Olagbemi. Adewole Akinwole Atere (PhD), (2011), Factors Affecting Small Scale Business Performance In Informal Economy In Logos State Negeria : A Gendered Based Analyisis, Department of Sociology Lagos State university Negeria. 